\title{
Reaksi Investor Atas Relevansi Informasi Arus Kas Dan Laba Akrual pada Laporan Keuangan Perusahaan
}

\author{
Muhammad Imam Sundarta, Azolla Degita Azis*, Anggita Citra Dewi \\ Fakultas Ekonomi dan Bisnis, Universitas Ibn Khaldun, 16161 Bogor, Indonesia \\ *Correspondence email: azolladegita@gmail.com
}

\begin{abstract}
Abstrak. Penelitian ini bertujuan untuk mengetahui adanya pengaruh informasi arus kas dan laba akrual terhadap reaksi investor yang terefleksi dalam return saham di industri manufaktur di Bursa Efek Indonesia dari periode 2013-2017. Penelitian ini merupakan penelitian kuantitatif dengan menggunakan data sekunder berupa laporan keuangan. Teknik analisis data yang digunakan berupa analisis regresi berganda. Hasil penelitian ini menunjukkan bahwa laporan arus kas tidak berpengaruh terhadap return saham, sedangkan laba akrual berpengaruh positif terhadap return saham. Temuan ini dapat menjadi salah satu literatur tambahan di bidang akuntansi keuangan karena investor melihat adanya informasi laba yang terkandung dalam laporan laba rugi dibandingkan laporan arus kas yang terefleksi dalam return saham.
\end{abstract}

Kata kunci: Informasi Arus Kas; Laba Akrual; Return Saham

Abstract. This study aims to determine whether cash flows and accrual earnings affect on stock returns that contained information about investors reaction in manufacturing industries on the Indonesia Stock Exchange from the 2013-2017 period. This research is a quantitative study using secondary data in the form of financial reports. The data analysis technique used is multiple regression analysis. The results of this study indicate that the cash flow statement has no effect on stock returns, while accrual earnings have a positive effect on stock returns. This finding can be one of the additional literature in the field of financial accounting because investors see the earnings information contained in the income statement compared to the cash flow statement that is reflected in stock returns.

Keywords: Cash Flow Information; Accrual Earnings; Stock Return

\section{PENDAHULUAN}

Laporan Keuangan merupakan salah satu sumber informasi keuangan bagi para investor untuk mengambil keputusan investasi. Laporan keuangan menyajikan informasi mengenai posisi keuangan, kinerja, dan arus kas perusahaan (Nurmalasari dan Yulianto, 2015). Tentunya didalam laporan keuangan juga mengandung informasi mengenai akrual dan arus kas yang dapat memprediksi laba masa mendatang perusahaan (Sloan, 1996). Hingga saat ini, masih terjadi perdebatan di kalangan peneliti mengenai relevansi informasi arus kas dan laba akrual terhadap return saham.

Return merupakan tingkat keuntungan yang dinikmati oleh investor atas tindakan investasi yang telah dilakukan (Nurmalasari dan Yulianto, 2015). Dalam investasi saham, investor akan lebih memilih saham perusahaan yang memberikan tingkat keuntungan tertinggi. Di sisi lain, return pun memiliki peran yang sangat signifikan dalam menentukan nilai dari suatu investasi. Informasi tentang arus kas suatu entitas berguna bagi para pengguna laporan keuangan sebagai dasar untuk menilai kemampuan entitas dalam menghasilkan kas dan setara kas tersebut (Ginting, 2012).

Secara umum, investor naif akan melihat informasi laba perusahaan karena menunjukkan kinerja keuangan perusahaan. Namun, penelitian Sloan (1996) mengungkapkan bahwa laba akrual mempunyai indikasi kurang persisten dibandingkan komponen arus kas. Hal tersebut dikarenakan perusahaan yang melakukan diskresi terhadap laba akrualnya akan mengakibatkan adanya kondisi abnormal return saham, sehingga tidak tercapai kondisi pasar yang efisien (market inefficiency). Informasi yang terkandung dalam laporan keuangan sejatinya dapat dijadikan sinyal bagi para investor untuk pengambilan keputusan dalam berinvestasi. Dalam signaling theory, reaksi pasar ditunjukkan dengan adanya perubahan volume dan harga perdagangan saham apabila terdapat pengumuman pendanaan internal perusahaan yang berasal dari arus kas operasi (CFO) lebih rendah (tinggi) pada masa mendatang (Nurmalasari dan Yulianto, 2015; Ramnath, 2002).

Laporan arus kas terdiri dari tiga aktivitas, yaitu aktivitas operasi, aktivitas investasi, dan aktivitas pendanaan (Nurmalasari dan Yulianto, 2015). Laporan arus kas harus disajikan dengan merinci komponen arus kas dari aktivitas operasi, investasi, dan pendanaan sehingga perubahan yang terjadi dari setiap komponen arus kas dapat dipergunakan untuk pengambilan keputusan manajemen berkaitan dengan ketiga aktivitas tersebut. Namun demikian, keberhasilan kinerja keuangan suatu perusahaan bergantung dari seberapa besar laba yang diperoleh sutu perusahan. Informasi laba pada umumnya merupakan perhatian utama dalam menaksir kinerja atau pertanggungjawaban manajemen di masa yang utama dalam menaksir kinerja atau pertanggung jawaban manajemen di masa yang akan datang. 
Terdapat beberapa penelitian terdahulu yang menginvestigasi hubungan antara arus kas dan laba terhadap return saham selama beberapa dekade terakhir (Bawono et al., 2020; Hung-Shu et al, 2015; Kasmiati dan Santosa, 2019; Rasyid dan Subekti, 2014; Kumar dan Krishnan, 2008). Ginting (2012) mengungkapkan bahwa informasi mengenai arus kas operasi dan laba berpengaruh terhadap return saham perusahaan. Namun, penelitian Ardiansyah et al. (2012), Ernayani et al. (2018) serta Nurmalasari dan Yulianto (2015) mengungkapkan bahwa arus kas tidak berpengaruh terhadap return saham. Anwar (2014) juga mengungkapkan bahwa informasi arus kas maupun laba tidak dapat berpengaruh terhadap return saham, sehingga menurut Anwar (2014) investor tidak menggunakan informasi arus kas dan laba akrual yang tertera dalam laporan keuangan untuk mengambil keputusan investasi sahamnya.

Beragamnya hasil penelitian terdahulu mengindikasikan bahwa topik ini masih menarik untuk dilakukan untuk melihat relevansi informasi laba akrual dan arus kas terhadap reaksi investor yang terefleksi dalam return saham. Sehingga, tujuan penelitian ini adalah untuk menguji secara empiris pengaruh informasi arus kas (arus kas operasi, investasi dan pendanaan) dan laba akrual terhadap harga saham. Penelitian ini memiliki implikasi yang berguna bagi para investor dan analyst mengenai dampak dari informasi arus kas dan laba akrual terhadap return saham perusahaan. Penelitian ini juga memiliki implikasi bagi dewan standar dan regulator, karena tambahan pengungkapan mengenai arus kas harus ditingkatkan relevansi informasinya agar dapat digunakan sebagai pengukuran yang dapat membantu para investor dalam menilai peluang investasi di suatu perusahaan.

\section{METODE PENELITIAN Model Penelitian}

Berdasarkan penelitian yang dilakukan oleh Ginting (2012) mengungkapkan bahwa informasi mengenai arus kas operasi dan laba berpengaruh terhadap return saham perusahaan. Sehingga informasi arus kas dan laba akrual diduga berpengaruh positif terhadap return saham seperti yang terlihat pada Gambar 1. Informasi tentang arus kas suatu entitas berguna bagi para pengguna laporan keuangan sebagai dasar untuk menilai kemampuan entitas dalam menghasilkan kas dan setara kas perusahaan. Sedangkan informasi mengenai laba perusahaan dapat menggambarkan kinerja keuangan perusahaan. Sehingga kandungan informasi arus kas dan laba akrual diduga memiliki relevansi informasi yang berguna bagi pengambilan keputusan investasi bagi para investor. Dengan demikian, hipotesis yang diajukan sebagai berikut:

$\mathrm{H}_{1}$ : Pertumbuhan arus kas dari aktivitas operasi berpengaruh positif terhadap return saham
$\mathrm{H}_{2}$ : Pertumbuhan arus kas dari aktivitas pendanan berpengaruh positif terhadap return saham

$\mathrm{H}_{3} \quad$ : Pertumbuhan arus kas dari aktivitas investasi berpengaruh positif terhadap return saham

$\mathrm{H}_{4} \quad$ : Laba akrual berpengaruh positif terhadap return saham

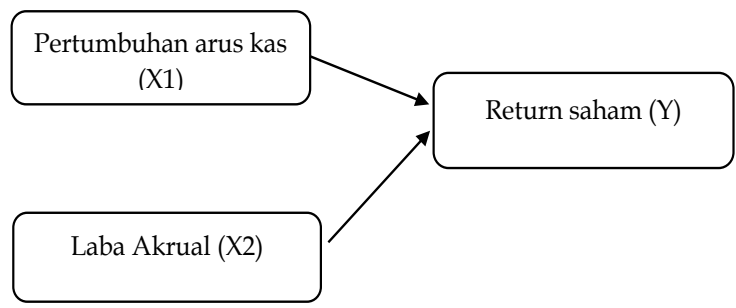

Gambar 1. Model Kerangka Penelitian

Adapun model untuk menguji hipotesis dalam penelitian ini yaitu:

$R E T_{i t+!}=\beta_{0}+\beta_{1} A O_{i t}+\beta_{2} A I_{i t}+\beta_{3} A P_{i t}+\beta_{3} G P_{i t}+u_{i t}$

Keterangan:

$R E T_{i t+1}=$ Return Saham perusahaan i pada tahun $\mathrm{t}+1$

$A O_{i t}=$ Arus Kas dari aktivitas operasi pada perusahaan i pada tahun $\mathrm{t}$

$A I_{i t}=$ Arus Kas dari aktivitas investasi pada perusahaan i pada tahun $\mathrm{t}$

$A P_{\text {it }}=$ Arus Kas dari aktivitas pendanaan pada perusahaan i pada tahun $\mathrm{t}$

$G P_{\text {it }} \quad=$ Laba Akrual pada perusahaan i pada tahun $\mathrm{t}$

$u_{i t} \quad=$ error terms

\section{Sampel Penelitian}

Sampel dalam penelitian ini adalah perusahaan manufaktur yang terdaftar dalam Bursa Efek Indonesia (BEI). Periode penelitian dimulai pada tahun 2013 hingga 2017 dengan total observasi sebanyak 30 observasi tahun-perusahaan. Sumber data dalam penelitian ini merupakan data sekunder yang diambil dari Datastream Worldscope Database untuk return saham dan annual report laporan keuangan perusahaan. Adapun proses seleksi pengambilan sampel dalam penelitian ini menggunakan metode random sampling.

\section{Operasionalisasi Variabel}

Peneliti menggunakan beberapa proksi untuk mengukur variabel dependen dan independent dengan menggunakan ukuran yang telah digunakan dalam penelitian terdahulu (Nurmalasari dan Yulianto, 2015; Ginting, 2012). Variabel dependen penelitian ini adalah return saham, yang berasal dari selisih harga pasar saham rata-rata diperoleh dari harga saham saat penutupan (closing price) setiap tahun. Persamaan dalam variabel ini adalah

$$
\mathbf{R i}=\mathbf{P}(\mathbf{t})-\mathbf{P}(\mathbf{t}-\mathbf{1}) / \mathbf{P}(\mathbf{t}-\mathbf{1})
$$


Keterangan :

$\mathrm{Ri}=$ Return saham.

$\mathrm{P}(\mathrm{t}) \quad=$ Harga saham pada periode sekarang

$\mathrm{P}(\mathrm{t}-1)=$ Harga Saham pada periode sebelumnya

Variabel independen penelitian ini adalah arus kas dari aktivitas operasi, arus kas dari aktivitas investasi, arus kas dari aktivitas pendanaan dan laba akrual yang telah digunakan pada penelitian sebelumnya (Nurmalasari dan Yulianto, 2015). Arus kas dari aktivitas operasi yang berasal dari total arus kas dari masing-masing aktivitas di dalam laporan arus kas pada saat dipublikasikan. Persamaan dalam variabel ini adalah:

$\mathbf{P A O}_{\text {it }}=\left(\mathrm{Ao}_{\text {it }}-\mathbf{A o}_{\text {it }}-1\right) / \mathrm{Ao}_{\text {it }}-1$

Keterangan :

$\mathrm{PAO}_{\text {it }}=$ Perubahan arus kas dari aktivitas operasi perusahaan i pada periode $t$.

$\mathrm{AO}=$ Arus kas dari aktivitas operasi perusahaan.

It $=$ Tahun periode pengamatan.

$\mathrm{AO}_{\mathrm{it}}-1=$ arus kas dari aktivitas operasi i pada periode $\mathrm{t}$ 1

Arus kas dari aktivitas investasi yang berasal dari total arus kas dari masing-masing aktivitas di dalam laporan arus kas pada saat dipublikasikan. Persamaan variabel ini adalah:

\section{PAIit $=($ Aiit - Aiit -1$) /$ Aiit -1}

Keterangan :

PAIit = perubahan arus kas dari aktivitas investasi perusahaan i pada periode $t$.

$\mathrm{Ai}=$ arus kas dari aktivitas investasi perusahaan.

It $\quad=$ periode tahun pengamatan.

Alit-1 = arus kas dari aktivitas investasi i pada periode $\mathrm{t}-1$.

Arus kas dari aktivitas pendanaan yang berasal dari total arus kas dari masing-masing aktivitas di dalam laporan arus kas pada saat dipublikasikan persamaan dalam variabel ini adalah:

\section{PAPit $=($ APit - APit -1$) /$ APit -1}

Keterangan :

PAPit = perubahan arus kas dari aktivitas pendanaan perusahaan i pada periode $t$.

AP $=$ Arus kas dari aktivitas pendanaan perusahaan $\mathrm{i}$ pada periode $t$.

It = periode tahun pengamatan.

APit-1 = Arus kas dari aktivitas pendanaan i pada periode $\mathrm{t}-1$.
Laba akrual yang berasal dari total laba akrual dalam laporan laba rugi. Pada saat dipublikasikan. Persamaan dalam variabel ini adalah

\section{PLKit $=($ LKit - LKit -1$) /$ LKit -1}

Keterangan :

PLKit $=$ perubahan laba akrual perusahaan $\mathrm{i}$ pada periode $t$.

Lk = Laba akrual perusahaan.

It $\quad=$ periode tahun pengamatan.

LKit-1 = laba akrual i pada periode $\mathrm{t}-1$.

\section{HASIL DAN PEMBAHASAN Pengujian Hipotesis}

Penelitian ini merupakan penelitian kuantitatif dengan menggunakan analisis regresi berganda Ordinary Least Square (OLS). Sebelum melakukan pengujian data, peneliti menguji apakah hasil regresi yang dilakukan telah terbebas dari permasalahan autokorelasi dan heteroskedastisitas. Peneliti telah menghilangkan permasalahan terjadinya varians yang tidak konstan dan terjadi otokorelasi dalam errornya, maka peneliti mengontrol standar errornya. Nilai Durbin Watson dari model return menunjukkan di kisaran angka 2 yang mengindikasikan bahwa hasil regresi tersebut telah terbebas dari permasalahan autokorelasi.

Model analisis data yang digunakan dalam penelitian ini adalah analisis Regresi Linier Berganda dengan data panel. Dari hasil uji chow dan uji hausman yang dilakukan, analisis data panel menggunakan Random Effect Model. Sedangkan statistik deskriptif data penelitian dapat dilihat pada Tabel 1. Sedangkan pada Tabel 2 menggambarkan hasil uji hipotesis dari masing-masing variabel independent terhadap variabel dependen.

Tabel 1. Statistik Deskriptif

\begin{tabular}{lccccc}
\hline & $\mathrm{N}$ & Minimum & Maximum & Mean & Std. Deviation \\
\hline Arus kas operasi & 30 &, 034 & 5,135 &, 70113 & 1,062089 \\
Arus kas investasi & 30 &, 016 & 1,828 &, 62213 &, 518826 \\
Arus kas pendanaan & 30 &,- 950 & 4,288 &, 93243 & 1,179410 \\
Laba akrual & 30 &, 008 &, 854 &, 23463 &, 210962 \\
Return saham & 30 &, 000 & 1,850 &, 43860 &, 481420 \\
Valid N (listwise) & 30 & & & & \\
\hline
\end{tabular}

Sumber: data sekunder yang diolah

Pada Tabel 2 dapat dilihat bahwa tidak adanya pengaruh positif pertumbuhan komponen arus kas dari aktivitas operasi maupun pendanaan. Oleh karena itu, Hipotesis H1 dan H3 ditolak. Sedangkan pertumbuhan komponen arus kas dari aktivitas investasi berpengaruh negatif terhadap return saham. Sehingga Hipotesis H2 ditolak. Hasil Penelitian ini sesuai dengan hasil pengujian pada penelitian Ginting (2012), Anwar (2014), serta Nurmalasari dan Yulianto (2015) yang menyatakan bahwa arus kas operasi, investasi, dan pendanaan tidak berpengaruh signifikan terhadap return saham. Ini 
disebabkan informasi yang terkandung dalam laporan arus kas belum sepenuhnya digunakan sebagai dasar pengambilan keputusan dalam pasar modal.

Namun demikian, temuan ini tidak sejalan dengan penelitian yang dilakukan oleh Ginting (2012) dan Bawono et al. (2020) yang menunjukkan bahwa informasi arus kas berpengaruh terhadap return saham. Menurut Bawono et al. (2020), komponen arus kas mengandung informasi penting terkait aktivitas operasi, distribusi pembagian dividen, dan keputusan investasi perusahaan tanpa mengandalkan pembiayaan eksternal. Informasi yang terkandung dalam arus kas perusahaan dianggap relevan bagi para investor sehingga terefleksi dalam return saham.

Tabel 2. Hasil Regresi

\begin{tabular}{lccccc}
\hline \multirow{2}{*}{ Independent Variable } & \multicolumn{5}{c}{ Dependent Variable: Return Saham } \\
\cline { 2 - 6 } \multicolumn{1}{c}{ (Constant) } &, 709 &, 166 & & 4,286 &, 000 \\
$\quad$ arus kas operasi &, 006 &, 092 &, 014 &, 068 &, 946 \\
$\quad$ arus kas investasi &,- 294 &, 149 &,- 385 & $-1,971$ &, 059 \\
$\quad$ arus kas pendanaan &, 042 &, 075 &, 111 &, 553 &, 585 \\
$\quad$ laba akrual &, 787 &, 371 &, 416 & 2,119 &, 044 \\
\hline R-Square & 0.451 & & & & \\
Adj. R-Square & 0.203 & & & \\
F-State & 6.721 & & & \\
N & 30 & & & & \\
\hline
\end{tabular}

Sumber: data sekunder yang diolah

Berbeda halnya dangan informasi laba akrual, berdasarkan Tabel 2 menunjukkan bahwa laba akrual terbukti berpengaruh positif terhadap return saham dengan nilai koefisien sebesar 0.78 dengan signifikansi level 5\%. Dengan demikian, Hipotesis H4 diterima. Hasil penelitian ini sesuai dengan hasil pengujian pada penelitian Ginting (2012) dan Bawono et al. (2020) yang menyatakan bahwa besaran laba berpengaruh secara signifikan positif terhadap return saham. Hal ini berarti besar kecilnya laba akrual berpengaruh terhadap besarnya return saham. Temuan ini mengindikasikan bahwa investor bereaksi terhadap angka laba akrual. Angka koefisien laba akrual yang tinggi menyebabkan investor mempercayai angka laba yang dilaporkan oleh emiten dibandingkan informasi arus kas.

\section{Pembahasan}

Pada dasarnya, laporan arus kas mengandung informasi arus kas melalui tiga jenis aktivitas, yaitu: (1) Arus kas dari aktivitas operasi adalah arus kas dari transaksi yang mempengaruhi laba bersih. Contohcontoh transaksi semacam itu mencakup pembelian dan penjualan barang dagang oleh pengecer atau retailer. (2) Arus kas dari aktivitas investasi adalah arus kas dari transaksi yang mempengaruhi investasi dalam aktiva tidak lancar. Contoh-contoh transaksi semacam itu meliputi penjualan dan pembelian aktiva tetap, seperti peralatan dan bangunan. (3) Arus kas dari aktivitas pembiayaan adalah arus kas dari transaksi yang mempengaruhi ekuitas dan utang perusahaan. Contoh transaksi seperti itu meliputi penerbitan dan penarikan sekuritas ekuitas dan utang. Laporan arus kas sebenarnya dapat menjadi parameter yang baik untuk melihat kinerja keuangan perusahaan (Bawono et al., 2020), karena mengandung informasi mengenai aktivitas perusahaan tanpa adanya informasi akrual didalamnya. Namun demikian berdasarkan hasil regresi yang telah dilakukan menunjukkan bahwa informasi arus kas tidak memiliki nilai relevansi bagi para investor di Indonesia.

Padahal, informasi mengenai laba tidak memiliki definisi yang menunjukkan makna ekonomi, seperti halnya elemen laporan keuangan yang lain. Oleh karena itu, konsep laba masih menjadi subyek perbedaan interpretasi dan perdebatan. Laba dapat dijadikan ukuran untuk menilai keberhasilan perusahaan. Pengukuran terhadap laba tidak akan memberikan informasi yang bermanfaat dan relevan bila tidak dapat menggambarkan kondisi perusahaan sebenarnya yang terefleksi dalam harga saham ataupun return saham (Rasyid dan Subekti, 2014).

Terlebih lagi jika perusahaan melakukan praktik manajemen laba, sehingga relevansi yang terkandung dalam informasi laba akrual perusahaan akan berkurang (Rasyid dan Subekti, 2014). Apabila perusahaan tersebut berada di negara yang memiliki proteksi terhadap investor yang lemah, maka pencatatan akuntansi secara akrual dapat menurunkan relevansi nilai dari laporan keuangan karena akan memberikan celah yang lebar bagi perusahaan untuk melakukan manajemen laba, sehingga relevansi nilai dari laporan keuangan akan semakin menurun. Pada dasarnya, informasi yang terdapat dalam laporan keuangan akan menjadi relevan, ketika investor memperoleh informasi mengenai laba dan arus kas perusahaan, dan mereka dapat menghitung nilai perusahaan sebenarnya (market value of the firm), maka dapat disimpulkan bahwa informasi yang terkandung dalam laba dan arus kas perusahaan tersebut menjadi relevan.

Temuan dalam penelitian ini menunjukkan bahwa investor di Indonesia lebih bersifat naif investor, karena lebih menggunakan informasi yang terkandung dalam laba akrual. Hal ini sejalan dengan temuan Richardson et al. (2005) yang menunjukkan bahwa investor yang naif akan lebih menyukai informasi laba, dan investor tersebut tidak mengantisipasi adanya kesalahan harga saham (mispricing) yang terjadi akibat penggunaan akrual dalam pencatatan akuntansi perusahaan. Selain itu, menurut Richardson et al. (2005), perusahaan yang memiliki reliabilitas dan relevansi akrual yang rendah memiliki persistensi laba yang rendah atau cenderung memiliki volatilitas laba yang tinggi, kondisi tersebut pada dasarnya tidak diantisipasi oleh investor yang cenderung bersifat naif.

\section{SIMPULAN}

Dalam penelitian ini dibahas mengenai reaksi investor yang terefleksi dalam return saham atas informasi yang terkandung dalam arus kas dan laba 
akrual perusahaan yang terdapat dalam laporan keuangan di industri manufaktur di Indonesia setelah diterapkannya konvergensi IFRS. Sehingga periode penelitian ini dimulai dari tahun 2013 hingga 2017. Dari pengujian yang telah dilakukan, secara konsisten menemukan bahwa investor lebih melihat informasi yang terkandung dalam laba akrual dibandingkan arus kas perusahaan. Hal ini sejalan dengan penelitian Bawono et al. (2020), Ginting (2012), dan Sloan (1996) yang mengungkapkan bahwa laba akrual mengandung informasi mengenai kinerja perusahaan, sehingga investor yang naif lebih memilih untuk menggunakan informasi laba akrual dibandingkan arus kas. Namun demikian, kandungan dalam laba akrual berpotensi mengandung unsur diskresi akrual yang dilakukan oleh manajemen perusahaan dibandingkan komponen arus kas.

Temuan dalam penelitian ini dapat menjadi bahan masukan bagi perkembangan penelitian akuntansi keuangan terkait dari relevan di informasi laba dan arus akus dalam laporan keuangan. Selain itu temuan ini dapat menjadi bahan masukan bagi regulator agar relevansi dan reliabilitas kandungan informasi laba serta arus kas dapat sejalan sehingga dapat digunakan oleh investor dalam mengambil keputusan investasi pada pasar modal. Penelitian ini memiliki keterbatasan dalam hal sampel penelitian yang hanya di Industri Manufaktur di Indonesia serta menggunakan data sekunder yang berpotensi memiliki measurement error. Untuk itu, penelitian selanjutnya diharapkan dapat memperluas sampel penelitian, dan menggunakan metode mixedmethod agar lebih komprehensif, serta mempertimbangkan variabel lainnya yang dapat berpengaruh terhadap reaksi investor seperti persistensi laba, manajemen laba, ataupun tata kelola perusahaan.

\section{DAFTAR PUSTAKA}

Anwar, A. (2014). Pengaruh Arus Kas dari Aktivitas Operasi dan Laba Akuntansi Terhadap Return Saham Perusahaan Industri Manufaktur yang terdaftar di BEI. Jurnal Akuntansi, 2, 3.

Ardiansyah, A, Ali, M., \& Djaya, Y. (2012). Hubungan Informasi Komponen Arus Kas dan Return on Invesment terhadap Return Saham. Skripsi: Universitas Hasanuddin, Makassar.

Bawono, A. D. B., Ramadhanti, M., \& Kurniawati, L. (2020). Earnings and Cash Flow Information on Its Value Relevance by The Book Value. Riset Akuntansi dan Keuangan Indonesia, 5(1), 46-53.

Ernayani, R., Prihandoyo, C., \& Abdiannur. (2018). Perubahan Arus Kas dan Pengaruhnya terhadap Return Saham. Jurnal Sosial Humaniora dan Pendidikan, 2, 1.

Hung-Shu, F., Yan-Ting, L., \& Chen, C. L. (2015). The Effect of Real Earnings Management on the Value-Relevance of Accounting Information. Tai Da Guan Li Lun Cong, 25(3), 163.
Kasmiati, M., \& Santosa, P. W. (2019). The effect of earning information, cash flow componens, firnancing decision, and Stock Return: Empirical Evidence on Indonesia stock exchange. Journal of Economics, Business \& Accountancy Ventura, 22(2), 157-166.

Kumar, K. R., \& Krishnan, G. V. (2008). The valuerelevance of cash flows and accruals: The role of investment opportunities. The Accounting Review, 83(4), 997-1040.

Nurmalasari, S.A.D., \& Yulianto, A. (2015). Analisis Pengaruh Perubahan Arus Kas Terhadap Return Saham. Management Analysis Journal, 4, (4), 289-300.

Ginting, S. (2012). Analisis Pengaruh Pertumbuhan Arus Kas dan Profitabilitas terhadap Return Saham pada Perusahaan LQ45 di Bursa Efek Indonesia. Jurnal Wira Ekonomi Mikroskil, 2, 1, 39-48.

Ramnath, S. (2002). Investor and Analyst Reactions to Earnings Announcements of Related Firms: An Empirical Analysis. Journal of Accounting Research, 40, 5, 1351-1376.

Rasyid, M. A., \& Subekti, I. (2014). The Effect Of Real Earnings Management On The Value Relevance Of Earnings, Book Value Of Equity, And Cash Flow From Operations. Jurnal Ilmiah Mahasiswa $F E B, 3(1)$.

Richardson, S. A., Sloan, R. G., Soliman, M. T., \& Tuna, I. (2005). Accrual reliability, earnings persistence and stock prices. Journal of accounting and economics, 39(3), 437-485.

Sloan, R.G. (1996). Do Stock Prices Fully Reflect Information in Accruals and Cash Flows About Future Earnings?. The Accounting Review, 71, 3, 289-315. 